\title{
PHONOLOGICAL FEATURES OF THE AMHARIC VARIETY OF SOUTH WOLLO
}

\author{
BAYE YIMAM
}

\section{ABSTRAC T}

This paper examines the phonological features that characterize the Amharic variety spoken in South Wallo, an area which has been influenced by the diffusion of linguistic and cultural features arising from longstanding contact situations between Semitic and non-Semitic linguistic groups. Data from eight districts of the zone have shown that the South Wallo variety has 26 consonant and seven vowel phonemes. The consonants are four fewer than that reported of the standard variety. The co-occurrence restrictions of the consonants and the syllable structures are the same as those of the standard variety. However, the phonological rules that operate at morpheme internal, morpheme and word boundary levels are different in the degree of complexity and directionality. These include intervocalic lenition of velar stops, word-final weakening of alveo-palatals, coalescence of lowering diphthongs, centering, lowering and fronting of vowels, metathesis of coronals and anteriors, and lexeme specific alternations of homorganic consonants. The description of the facts provides more substantive arguments in favor of the long-held claim that Wallo constitutes a distinct dialect area.

\section{[1] INTRODUCTION}

Amharic is the working language of the Federal Democratic Republic of Ethiopia. It is the most widely spoken Semitic language serving as a national lingua franca. It is a medium of instruction in elementary schools in the Amhara Regional State and in major urban areas in other states. It is a field of study in colleges and universities. It has a relatively rich literature that dates back to the turn of the $20^{\text {th }}$ century, and a history of writing that goes back to the $14^{\text {th }}$ century, (Appleyard 2003: 233). There are books on its grammar, lexicon, and creative writings of all genres.

One aspect of the language that has not been given enough attention is the degree of variations it shows across regions and social groups (Amsalu and Habtemariam 1973:114). The few attempts that have been made indicate the following as possible areas of dialect variations (Amsalu and Habtemariam 
1973; Hailu et al. 1976):

Wallo

Gondər

Goj̃am

Mənz (Shewa)

Addis Ababa.

The identification of these areas is based on lexical and phonological features of data from semi-urban areas in Wallo, Goj̃am, and Mənz.

This situation calls for a more comprehensive and in-depth study than could be undertaken here. Therefore, the present paper focuses only on Wallo, and specifically South Wallo (SW), which has witnessed processes of ethnic and religious interactions over an extended period of time (Hussein 2001). Among the interacting groups are Amhara, Oromo and Argobba Christians and/or Muslims whose contacts have had an effect on the formal and functional aspects of the language used in the area. The present study is, thus, an attempt towards describing the phonological features that characterize the area.

To this effect, the paper is organized into five sections, the first of which is a brief introduction. The second section gives a brief overview of previous studies on variations as a point of departure. Sections three and four address the phonemic inventory and the various phonological processes attested in the present corpus, and finally, section five provides a short summary.

\section{[2] PREvious studies}

Dialect studies are a recent phenomenon in Ethiopian linguistics (Amsalu and Habtemariam 1973). Their history goes back to the late 1960s and mid 70s, when work started as part of a descriptive survey project on language use and language teaching in Eastern Africa. Four teams set out to do the survey in the four Amharic speaking provinces of Bəgemidir (now Gondər), Goj̃am, Wəllo, and Mənz of Shewa. Subsequently other surveys were undertaken on the major languages of the Cushitic, Omotic, Semitic and Nilotic stalks, the results of which were published in Bender et al. (1976).

Following these studies, certain Oromo and Amharic speaking regions were recognized as dialect areas (Hailu, Getachew and Cowley 1976; Gragg 1976; Kebede 2009). Among them was Wallo, which Amsalu and Habtemariam (1973) had already identified as a possible dialect continuum with Monz of Shewa. The claim was later supported with studies by Getahun (1983), Gebre (1999) and Zelealem (2007). Getahun (1983) is an essay on the same Wallo area with data from the locality of Ambassal, some $60 \mathrm{~km}$ north of Dase, the capital of the pre- 
sent South Wəllo Zone. The data in Amsalu and Habtemariam (1973) was from Haik', a small town $30 \mathrm{~km}$ north of Dəse, and from nearby villages such as Sulula.

The focus of these studies was on some general phonological and morpholexical features of Amharic for which the Addis Ababa variety, which was considered a de facto standard variety (SV) due to its connection with the power elites and the bureaucracy, was taken as a measure against which variations were described and judged (Amsalu and Habtemariam 1973).

The phonological descriptions showed that there were two types of alveodental stops: one consisting of $/ \mathrm{d} /$ and $/ \mathrm{t} /$, and the other comprising the alveopalatal counterparts $\left[\mathrm{d}^{\mathrm{y}}\right]$ and $\left[\mathrm{t}^{\mathrm{y}}\right]$. Whether the latter two consonants were phonemic entities or allophonic variants of the former two is not clear from the descriptions.

The same descriptions also showed that there was a palatalization process which reduced the alveo-dental stops $/ d /$ and $/ t /$ to [č ] and [j] in the context of a following high front vowel. However, such processes are not unique to the Wallo variety as they are also attested in other dialects such as Mənz (Hailu and Fisseha 1973), in North Shewa, and in South Gondər, as reported in Gebre (1999). The feature may cover a chain of areas from South Gondər to North Shewa, with South Wallo (SW) falling in between. What seems unique to SW is the further weakening of these same alveo-palatals, /č/ and / ̌ /, to [y], as will be shown in section four.

The survey by Amsalu and Habtemariam (1973) also showed that the variety of Wallo is characterized by a large number of Arabic and Oromo loan words, resulting from longstanding secular and religious contacts between and among speakers of these languages or dialects. It is reported that the present day South Wallo has become one of the major centers of Islamic teaching, for which a variety of Arabic has been in use along with Amharic (Hussein 2001; Rukia 2013). Such contacts between Christian and Muslim Amharas have been so close that the two languages have influenced each other, with the Amharic lexicon becoming Arabicized, and the Arabic one getting Amharicized. ${ }^{1}$ The Arabicized Amharic lexicon has now led to the emergence of a special sub-variety dubbed Muslim Amharic (Pankhurst 1994; Rukia 2013:128).

The contact between Amharic and Oromo is as old as the $17^{\text {th }}$ century, which was marked by the Oromo expansion to the north following the Jihadist conquest of the country by Ahmad bin Ibrahim al Gazi (1506-1543). There has been

[1] Examples of Amharicized Arabic words include indiris for Idris; aj̃b for Sujib / SajaSib; ǰuma/ǰimmat for juma\{a; səyid for Said, gyism for jism 'body', adduñña for addunya <al-dunya 'livelihood, world', šeralla for sharia Allah, merebba for merhaba 'may it be so' etc. 
a diffusion of Oromo morpho-lexical features into Amharic, and a large number of lexical items defused from Amharic into the variety of Oromo used by the expansionists. This is in addition to features that are claimed to have come into Amharic from a Cushitic substratum, more particularly from the Agaw languages of central and northern Ethiopia (Leslau 1945, 1964; Appleyard 1977). From this, one may conjecture that Amharic is a sandwich language of an Agaw base and an Oromo topping, decorated with a thin layer of Arabic lexicon. This is evident from its basic lexicon which is reported to be $25 \%$ non-Semitic, and its head-final syntax which is fully Cushitic, (Appleyard 1977; Bender 1983). As stated in Amsalu and Habtemariam (1973), the lexical influence of Oromo and Arabic has been more noticeable in the Wallo area than in other parts of the Amharic speaking regions of the country.

\section{[3] THE PRESENT STUDY}

As stated above, the data for the previous studies was gathered from urban and semi-urban areas in South Wallo, specifically in Dase, Haik' and in adjacent districts such as Ambassal, all within a radius of $60 \mathrm{~km}$. In contrast, the data for the present study comes from a broader area, that includes eight of the 20 districts of the South Wallo Zone. ${ }^{2}$ These districts have been selected since they show a great deal of religious and ethnic interactions.

The data was gathered through elicitation of lexical items of cultural and natural objects, and audio - video recordings of oral narratives, such as reminiscences ${ }^{3}$ of elders and youngsters of both sexes, stories, and two Ajami texts by two Sheikies from Dase. The present corpus may, thus, provide a broader spectrum of facts for a more comprehensive description, which may, in the end, support or militate against the claim that Wallo in general constitutes a dialect area. For this, the study takes the phonetic and phonological properties of consonants and vowels attested in the present corpus as its major concern.

The approach adopted for the description is synchronic, and eclectic in the sense that both stracturalist and generative concepts and descriptive tools are used. The phoneme is recognized as a distinctive unit of sound and/or as a bundle of distinctive features, depending on the nature of the facts that need explaining.

[2] These are Wərrə Babo, Wərə Ilu, K'alu, Ləgə Hida, Borəna, Tənta, Ambassəl, and Təhulədəre.

[3] Four elderly male, five young male and five female native speakers, with ages ranging from 18 to 81 , have been consulted. 


\section{[4] PHONOLOGY}

In this section, the consonant and vowel sounds attested in the present corpus are described. To this end, the inventory of the consonant and vowel phonemes of the standard variety (SV) of the language will be used as a contrastive background, but not as a derivative basis for the variations shown in the SW variety shows.

\section{[4.1] Consonants}

From the elicited data and recorded narratives, the following consonant phones have been identified.

\begin{tabular}{|c|c|c|c|c|c|}
\hline Bilabial & $\begin{array}{l}\text { Labio- } \\
\text { dental }\end{array}$ & $\begin{array}{l}\text { Alveo- } \\
\text { dental }\end{array}$ & $\begin{array}{l}\text { Alveo- } \\
\text { palatal }\end{array}$ & Velar & Glottal \\
\hline$b b^{y}$ & & $\mathrm{~d} \mathrm{~d}^{\mathrm{y}}$ & $\check{\mathrm{j}}$ & $g g^{y} g^{w}$ & \\
\hline$(p)$ & & $\mathrm{t}^{\mathrm{y}}$ & č & $\mathrm{k} \mathrm{k}^{\mathrm{y}} \mathrm{k}^{\mathrm{w}}$ & $?$ \\
\hline$\left(p^{\prime}\right)$ & & $t^{\prime} t^{\prime y}$ & $\check{c}^{\prime}$ & $k^{\prime} k^{\prime y} k^{\prime w}$ & \\
\hline$\beta$ & $\mathrm{ff}^{\mathrm{y}}$ & $\mathrm{z} \mathrm{z}^{\mathrm{y}}$ & $\check{z} \check{s}$ & y x x' & $\mathrm{h} \mathrm{h}^{\mathrm{w}}$ \\
\hline $\mathrm{m}$ & $\mathrm{m}$ & $\mathrm{s} \mathrm{s}^{\mathrm{y}}\left(\mathrm{s}^{\prime}\right)$ & $\tilde{\mathrm{n}}$ & $y$ & \\
\hline $\mathrm{w}$ & & $\mathrm{n} \mathrm{r} \mathrm{r} \mathrm{r}^{\mathrm{y}} 1 \mathrm{l}^{\mathrm{y}}$ & $\mathrm{y}$ & & \\
\hline
\end{tabular}

TABLE 1: Consonant phones of the South Wallo Variety (SWV).

Out of these 49 consonant phones, those in brackets, (p), (p') and (s'), are found in loan words of English, Greek and Gi'iz. They are thus marginal as their distribution is restricted to just a few such words. The native plosives, liquids, and coronal fricatives have alveo-palatal and round counterparts, attested in the following examples from SW: 


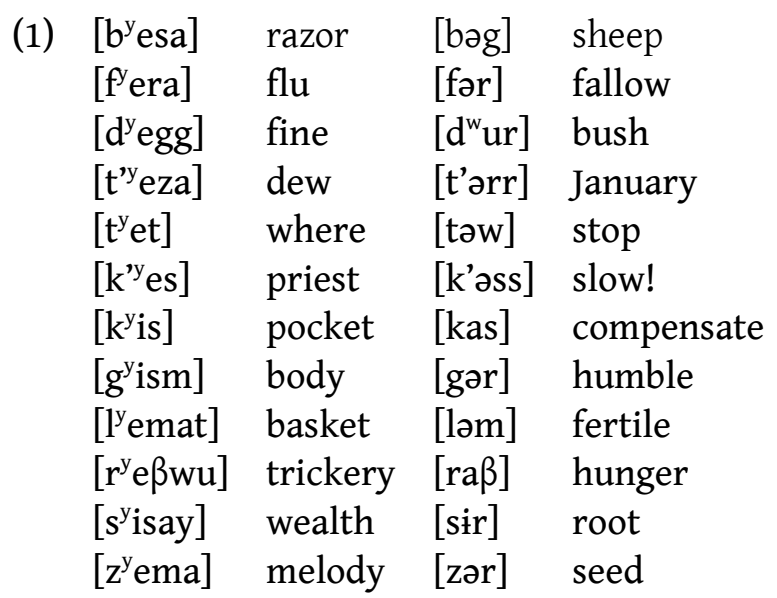

The initial consonants in each of the words in the left column are followed by the front vowel [e] or [i] which seems to trigger the palatalization of the consonants. In the corresponding words in the right column, which are from the same variety, the same consonants do not undergo palatalization because they are not followed by the front vowels. This suggests that the palatalized initial consonants in the words of the left column are allophonic variants of their plain counterparts in the words of the right column.

However, there are examples which also suggest that the palatalized consonants could be phonemic entities rather than allophonic variants. Evidence for this possibility comes from the data below, where the palatalized consonants appear preceding the low mid front vowel [æ], a segment which has not been attested in the standard variety (SV), and in the reports of previous studies. SWV:

(2) [ $\mathrm{d}^{\mathrm{y}}$ æa $]$ problem [ $\mathrm{d}^{\mathrm{y}}$ æs $]$ shade

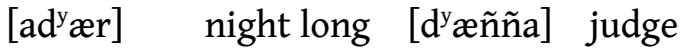

[addy $æ$ Adam [dy

[id $\mathrm{id}^{\mathrm{y}}$ ] debt $\quad\left[\mathrm{ad}^{\mathrm{y}} æ\right]$ and so

[maləd$\left.d^{y} æ\right]$ morning [arady $\left.{ }^{y} æ\right]$ urbane

[gady distance [b] $æ$ [ssa] city center

The palatalized consonants are found in syllabic onset positions, which may imply that such positions may be specified for segments which have the features [+HIGH, - BACK], in the sense of Chomsky and Hale (1968), and in subsequent literatures. However, there is evidence to the contrary which will be provided in section four.

The labial fricative $[\beta]$, the labio-dental $[\mathrm{m}]$ and the velar nasal [ $\eta]$ are allo- 
phonic variants of $/ b /$, and $/ n /$, respectively. This is consistent with the pattern in the standard variety (SV), as the following examples in phonetic transcription demonstrate.

(3) /leba/ [le $\beta a]$ thief /kənfər/ [kəmfər] lip /angat/ [angət] neck /anfət'/ [amfət'] colored

The velar fricatives $[\mathrm{x}],\left[\mathrm{x}^{\prime}\right]$ and $[\mathrm{y}]$ in table 1 were not reported in previous studies, but have been attested in the present corpus as being allophonic variants of the corresponding stops $/ \mathrm{k} /, / \mathrm{k}^{\prime} /$ and $/ \mathrm{g} /$, respectively. They occur in post-vocalic position, as in the following examples from the SW variety.

$\begin{array}{llllll}\text { (4) /hagər/ } & \text { [hayər] } & \text { country } & \text { /gəragər/ } & \text { [gərayər] } & \begin{array}{l}\text { unsus- } \\ \text { pecting } \\ \text { thief }\end{array} \\ \text { /alləh/ }[\text { alləx] } & \begin{array}{l}\text { you } \\ \text { have }\end{array} & \text { /sərak'i/ } & \text { [sərax'i] } & \text { then }\end{array}$

In the same way, the glottal stop [?] occurs as a free variant of the ejective stop $/ \mathrm{k}$ / found in post-vocalic positions as in the following examples:

(5)

\begin{tabular}{|c|c|c|c|}
\hline & SWV & SV & \\
\hline / bək'əddəm/ & [bə2əddəm] & [bək'əddəm] & just a while back \\
\hline / mak'annət/ & [mə?ənnət] & [mək'ənnət] & girdle \\
\hline /t'abbik'/ & [t'əbbi?] & [t'əbbik'] & wait for \\
\hline
\end{tabular}

It also appears that in the SWV, [̌̌] is a free variant of $/ \check{\jmath} /$ in nearly all forms, except in [ẫja ] 'oats', [î̃jag] 'very' and [î̃j] 'hand', where only the affricate is possible. Similarly, the palatal affricate [č] freely alternates with the fricative [š] in initial and medial positions in the noun [šəggər], [čəggər] 'problem', and in the corresponding verbs [təčəggərə] [təšəggərə] 'vexed' and [aččənnəfə] [aššənnəfə] 'won'. In the standard variety, it is only the affricate which is more frequent. ${ }^{4}$

Out of the 49 consonants in Table 1 , only 26 of them have phonemic status; the rest are allophonic variants occurring in free or complementary distributions. The phonemes of the SW variety are, thus, the following:

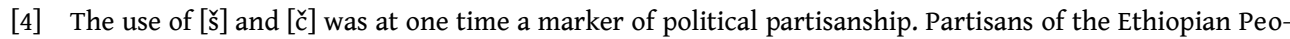
ple's Revolutionary Party (EPRP) used [č] in the word [innaččənnifallən!], whereas partisans of the All Ethiopian Socialist Movement (AESM) used [š] instead of [č] in the same word, thus [innaššənnifallan!], both meaning 'We Will Win!', an example of politically sensitive language use. 


\begin{tabular}{cccccc}
\hline Bilabial & $\begin{array}{c}\text { Labio- } \\
\text { dental }\end{array}$ & $\begin{array}{c}\text { Alveo- } \\
\text { dental }\end{array}$ & $\begin{array}{c}\text { Alveo- } \\
\text { palatal }\end{array}$ & Velar & Glottal \\
\hline $\mathrm{b}$ & & $\mathrm{d}$ & $\check{\mathrm{j}}$ & $\mathrm{g}$ & \\
$(\mathrm{p})$ & $\mathrm{f}$ & $\mathrm{t}$ & $\mathrm{c}$ & $\mathrm{k}$ & \\
$\left(\mathrm{p}^{\prime}\right)$ & & $\mathrm{t}^{\prime}$ & $\check{\mathrm{c}}$ & $\mathrm{k}$ & \\
$\mathrm{m}$ & & $\mathrm{s}\left(\mathrm{s}^{\prime}\right) \mathrm{z}$ & $\check{\mathrm{s}}(\check{\mathrm{z}})$ & & $\mathrm{h}$ \\
$\mathrm{w}$ & & $\mathrm{n} \mathrm{r} \mathrm{l}$ & $\tilde{\mathrm{n}}$ & & \\
& & & $\mathrm{y}$ & & \\
\hline
\end{tabular}

TABLE 2: Phonemes of the SW variety.

These phonemes correspond to 26 of the 31 phonemes of the standard variety, in which, the labio-velars $/ \mathrm{g}^{\mathrm{w}} /, \mathrm{k}^{\mathrm{w}} /, \mathrm{k}^{\mathrm{w}} /$ are treated as phonemes. In the present corpus, these have been identified as variants of the plain counterparts, occurring in the context of a following back vowel, as in words like [ $\mathrm{g}^{\mathrm{w}} \mathrm{um}$ ] 'mist', [ $\left.\mathrm{k}^{\mathrm{w}} \mathrm{ul}\right]$ 'eye line', [ $\left.\mathrm{t}^{\mathrm{w}} \mathrm{\textrm {w }} \mathrm{om}\right]$ 'fasting' and [ $\left.\mathrm{k}^{\mathrm{w}} \mathrm{wlf}\right]$ ' $\mathrm{key}$ ', as has also been argued in Taddese (1972) for the SV.

The 26 phonemes of the SW variety can occur in all positions in a word, and that all, but /h/occur geminate in non-initial positions. The feature is both grammatical and lexical, as the opposition in the following examples shows:

(6) /sabr-/ break /gənna/ Christmas /sabbar-/ broke /gana/ not yet

From the facts observed thus far, one would conclude that the assumed SW variety has 26 consonant phonemes. The glottal stop and the labio-velars are allophonic variants. [j] and [ž] are free variants in almost all cases, and that [ᄃ̌] and [ $\check{s}]$ alternate in only two nouns and in their corresponding verbs.

\section{[4.2] Vowels}

The vowel sounds that have been attested in the present corpus are the following:

\begin{tabular}{lll}
\hline $\mathrm{i}$ & $\dot{\mathrm{i}}$ & $\mathrm{u}$ \\
$\mathrm{e}$ & ə & $\mathrm{o}$ \\
$æ$ & $\mathrm{a}$ & - \\
\hline
\end{tabular}

TABLE 3: Vowels of the SW Variety. 
These vowels are found in examples like the following, all from the SW variety.

(7)

$\begin{array}{llllll}{\left[\mathrm{t}^{\mathrm{y}} \text { is }\right]} & \text { smoke } & {[\mathrm{izzih}]} & \text { here } & {\left[\mathrm{m}^{\mathrm{w}} \mathrm{uk} \mathrm{k}^{\prime}\right]} & \text { warm } \\ {\left[\mathrm{s}^{\mathrm{y}} \mathrm{et}\right]} & \text { woman } & {[\mathrm{borr}]} & \text { gate } & {\left[\mathrm{m}^{\mathrm{w}} \mathrm{ot}\right]} & \text { death } \\ {\left[\mathrm{d}^{\mathrm{y}} \mathrm{rr}\right]} & \text { side } & {[\mathrm{bal}]} & \text { husband } & {\left[\mathrm{t}^{\mathrm{w}} \mathrm{om}\right]} & \text { fasting }\end{array}$

Table 3 above shows that there is an asymmetry in the inventory, since there are only two back vowels, [u] and [o], corresponding to the three front vowels, [i], [e] and [æ]. This may cast some doubt on the status of [æ]; it could be an allophonic variant of the low central vowel [a], occurring immediately after palatalized alveo-dental consonants such as $\left[\mathrm{d}^{\mathrm{y}}\right]$ and $\left[\mathrm{t}^{\mathrm{y}}\right]$, as in the examples in the first column in (7). If this assumption is correct, then the phonemic representation of forms such as [ $\left.d^{y} æ r\right]$ in (7) would have to be / $d^{y}$ ar/. But this claim faces a problem because it implies that consonants like $\left[\mathrm{d}^{y}\right]$ are phonemes. The fact that such consonants occur in the environment of a following front vowel /i/ or /e/ makes them phonologically conditioned variants of the plain counterparts. Secondly, there are no minimal or analogous pairs where, for example, $\left[d^{y}\right]$ and $[d],\left[t^{y}\right]$ and $[t]$, etc. show contrast in meaning.

An alternative argument would be one that treats the vowel [æ] in forms like [dy $\mathrm{d}^{\mathrm{y}}$ ] as a result of coalescence of /i/ and /a/. In that case, the phonemic representation of forms like [ $\mathrm{d}^{\mathrm{y} æ r}$ ] would be /diar/ in the SW variety. Support for this line of argument comes from the SV where sequences of /i/ and /a/ are possible in phonemic representations of forms like the following.

(8) /k'aria/ green pepper /zabia/ handle /t'abia/ station /kaffia/ drizzle

It is possible that in the SW variety, in such forms as /diar/ 'side', the high front vowel /i/ causes the consonant preceding it to get palatalized and then it (/i/) coalesces with /a/. Thus, the phonemic representation of forms such as/k'aria/ surface as [k'ar $\left.{ }^{y} æ\right]$ 'green pepper' or [t'aß $\left.{ }^{y} æ\right]$ 'station' after coalescence in the SW variety. In the SV, instead of coalescence, /i/ gets weakened to [y] such that forms like /t'abia/ surface as [t'aßya] at the phonetic level. It seems that the two varieties apply different rules - coalescence or weakening on their respective phonemic representations. ${ }^{5}$

All other vowels of the SW variety are short and simple. The lax vowels /ə/

[5] A reviewer commented that each variety should be treated on its own, with which I fully agree. The phonemic inventory and the co-occurrence restrictions of the phonemes and the syllable structures of each variety are the same. The difference is in the type of phonological processes that take place at the various levels in each variety, or in the directionality of the processes. 
and /a/ occur in all positions, except that /ə/ is restricted to a non-final position. Consider the following:

$\begin{array}{llll}\text { (9) /ibd/ mad /arəg/ interjection of surprise } & \text { /abbat/ } & \text { father } \\ \text { /bird/ cold /k’ərrə/ failed to come } & \text { /asa/ fish }\end{array}$

The tense vowels /i/ /e/ /o/ and / $\mathrm{u} /$ have not been attested in word initial positions in the present corpus, which is consistent with what is reported of them in the standard variety (Baye 2000).

From the facts observed thus far and the arguments forwarded, it is possible to keep the claim that the SW variety has seven short vowels, and 26 consonant phonemes. In the following, the phonological processes that operate on structures of syllables, morphemes and lexemes will be described.

\section{[4.3] Phonological Processes}

This sub-section describes the phonological processes that take place within morphemes, across morpheme and word boundaries. For this, it is necessary to start with the syllable structure of the SW variety. It has the pattern: (C) V (C) (C), where geminates count as two consonants, taking onset and coda positions, as in /dab.boh/ 'your bread' and in /work' / 'gold', which has a branching coda. Clusters of no more than two consonants are allowed in non-initial position. In this regard, the SW variety behaves like the SV, their differences being in the type, manner and directionality of the phonological rules which are described next.

\section{Morpheme internal assimilation}

In the SW variety, the voiced alveo-dental stop / $d /$ changes to the continuant [r] in the context of a following continuant such as $/ \mathrm{m} /$ or $/ 1 /$, as in the following examples:

\begin{tabular}{|c|c|c|c|}
\hline & $\begin{array}{l}\text { SWV } \\
{\left[\text { irmm }^{y_{0}}\right]^{6}}\end{array}$ & $\begin{array}{l}\text { SV } \\
\text { [irme] }\end{array}$ & 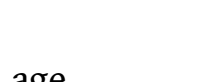 \\
\hline /wadla/ & [warla] & [wadla] & place name \\
\hline /k'admo/ & [k’orm $\left.{ }^{\mathrm{w}} \mathrm{o}\right]$ & [k'ədm $\left.{ }^{\mathrm{w}} \mathrm{o}\right]$ & before \\
\hline /gudba/ & {$\left[g^{\mathrm{w}} \mathrm{ur} \beta \mathrm{a}\right]$} & {$\left[g^{\mathrm{w}} \mathrm{ud} \beta \mathrm{a}\right]$} & ditch \\
\hline
\end{tabular}

The same consonant /d/ optionally turns into its voiceless counterpart [t] in

[6] A reviewer questioned why [irm ${ }^{y}$ ] cannot be taken as a phonemic representation for the SW variety. The fact is that both [irm ${ }^{y}$ e] and [idme] are used in the same SW variety, with the latter more widespread. The former is restricted to rural areas, and it is plausible to derive it from the more widespread form, /idme/, as it is less costly and leads to greater generalization. 
final position in the word for 'yes' in the SW variety. The form occurs as [awad] or [awət] ${ }^{7}$ both based on the cognate [awə] used in the standard variety with an optional /n/, as in [awən]. There are, thus, three variants: [awəd] [awət] used in the SW variety, and [awən] used in the SV for the same concept of affirmation.

The bilabial nasal $/ \mathrm{m} /$ changes to the alveolar counterpart [n] in the bound imperative stem [-nt'a] 'come' in the SW variety. The root of this stem is $/ \mathrm{m}-\mathrm{t}$ '$?$ / 'come' in the SV. The initial consonant $[\mathrm{m}]$ is attested in the form of the perfective stem /mat't'a/ 'came' in the same variety. In the SW variety, however, $/ \mathrm{m} /$ assimilates to the coronal obstruent [ $\left.\mathrm{t}^{\prime}\right]$ in place, and appears as [n]. Hence, the bound imperative form is [-nt'a] 'bring' from which the SW variety derives the causative [ant'a] lit. 'cause to come' (= bring), the optative, [yi-nt'a] 'let him come', and the permissive/consultative [li-nt'a] 'may I come?' all showing [n], whereas in the SV these forms occur with a $/ \mathrm{m} /$.

As stated in the introduction, anterior and coronal consonants undergo morpheme internal palatalization in the environment of a following front vow$\mathrm{el} / \mathrm{i} /$ or /e/. Examples of forms in which the rule applies include the following:

\begin{tabular}{|c|c|c|c|c|}
\hline & $\begin{array}{l}S W V \\
{\left[d^{y} e s^{y} e\right]}\end{array}$ & name of a town & /dəse/ & $\begin{array}{l}\text { SV } \\
\text { [dəse] }\end{array}$ \\
\hline & {$\left[s^{y}\right.$ era] } & cons & $/ \mathrm{se}$ & [sera] \\
\hline & [1'yemat] & basket & $/$ le & [lemat] \\
\hline /meda/ & [my eda] & field & & [meda] \\
\hline /keša/ & {$\left[k^{y} e s ̌ a\right]$} & sack & /keša/ & [keša] \\
\hline & {$\left[\mathrm{t}^{\mathrm{y}} \mathrm{is}\right]$} & smoke & $/ t^{\prime}$ is/ & \\
\hline /t'eza/ & [tyeza] & dew & /t'eza/ & [t'eza] \\
\hline
\end{tabular}

The plain consonants / $m, d, s, l, n, t^{\prime}, k$ / change to $\left[m^{y} \cdot d^{y}, s^{y}, l^{y}, n^{y}, t^{y y}, k^{y}\right]$ in the SW variety only, where the [+HIGH] feature is more noticeable (Baye 2000). Note that the form [ $d^{y}$ ese] has different phonemic representations: /dese / in SWV, and /dase/ in the SV. This means that the difference between the two varieties could be representational in the sense that they show different phonemic vowels /e/ or /ə/ in the first syllable of the same noun.

In the SW variety, regressive assimilation in devoicing is attested in the forms [dəftər] 'exercise book' and [dəftəra] 'cleric'. In the standard variety, these forms have the phonemic representations, /dəbtər/ and /dəbtəra/, respectively, and phonetic realizations, [dəßtər] and [dəßtəra]. The bilabial stop

[7] Substitution of [n] by [d] or [t] is also reported about the same word in the Mənz area of North Shewa, which is immediately south - adjacent to SW with which it forms a chain. 
$/ \mathrm{b} /$ undergoes lenition and surfaces as $[\beta]$ in the context of a preceding vowel. In the SW variety, however, a process of devoicing of $[\beta]$ to $[\mathrm{f}]$ is triggered by the $[-\mathrm{VOICE}]$ feature of $/ \mathrm{t} /$ following it $([\beta])$. The difference between the two varieties is that only lenition takes place in the SV, whereas both lenition and devoicing take place in the SW variety, which makes the variety complex ${ }^{8}$.

\section{Metathesis}

A few cases of morpheme internal metathesis have been observed in both nominal and verbal forms in the SW variety. The following have been selected on the assumption that they may be unique to the variety.

\begin{tabular}{|c|c|c|}
\hline [gadd $\mathrm{y}$ efə] & $\begin{array}{l}\text { SWV } \\
\text { supported }\end{array}$ & $\begin{array}{l}\text { SV } \\
\text { [dəggəfə] }\end{array}$ \\
\hline [məg $\left.{ }^{\mathrm{w}} \mathrm{os}\right]$ & charisma & {$\left[\mathrm{m}^{\mathrm{w}}\right.$ ogəs] } \\
\hline [səmmət'ə] & he sank & [sət't'วmə] \\
\hline [bələk'] & a flexible twig & [ləßək'] \\
\hline [mikk $\left.{ }^{\mathrm{w}} u t\right]$ & fattened sheep or goat & [mw ukkit] \\
\hline$\left[\right.$ mərt'əß $\left.\aleph^{\mathrm{y}} \mathrm{a}\right]$ & axe & [mat'rəß口$\left.\aleph^{y} a\right]$ \\
\hline [irfət] & recess & [irəft] \\
\hline [it't'əjəbbaß] & shirt & [ił̌jat't'วbbaß \\
\hline
\end{tabular}

In the SW variety, word - initial and medial consonants, and word - medial and final consonants, switch positions as in: [gədd' efə] and [dəggəfə] 'supported', and [səmmət'ə] and [sət't'əmə] 'sank', respectively. In these forms, the medial consonant is a geminate, whereas the initial and the final ones are simple. When the geminate shifts to the initial position, it becomes simple (degeminates), and when the simple ones shift to the medial positions, they become geminate. In other words, the rule requires that a metathesized segment matches its feature with the specific feature [+ gemination] or [- gemination] of the position it shifts to.

In the forms /bəlak'/ 'flexible stick', the first and the second consonants, and in /mat'rabiya/ 'axe' the second and the third consonants, swap position. Both forms are nouns and behave differently from the verbal ones in which

[8] A reviewer commented that dəftər 'notebook' is Arabic, originally a loan from Greek, and what seems to be taking place in the standard variety of Amharic is a sound change $/ f />/ b /$. This is true but (1) the change is not only $/ \mathrm{f} />/ \mathrm{b} /$; it is also $/ \mathrm{a} />/ \mathrm{\partial} /$; (2) if we take the Arabic loan as a base, one can account for the change of $/ \mathrm{f} />/ \mathrm{b} /$ in a synchronic or diachronic voicing rule applying to $/ \mathrm{f} /$ and resulting in $[\beta]$ in the SV, and with no such a rule applying to $(/ f /)$ in SW variety. The rule, whether synchronic or diachronic, is post-vocalic voicing. There are examples of loan words where a similar process takes place. One such example is the English loan word /polis/ in which /p/ is weakened to the continuant [f] or becomes voiced, [b], in the SW variety, thus leading to either [folis] or [bolis], both due to the vowel following /p/ in /polis/ 
gemination plays a grammatical role. In addition, in those forms in the second column in (12) above, the first vowel swaps position with the second in the first two, and the second vowel and the continuant consonant immediately following it also exchange positions. It appears that in almost all cases, the SW variety seems to favor central vowels in initial syllables, and an obstruent before a non-obstruent, a coronal before an anterior in stems. The pattern of preference is shown in (13) below, which shows the list of the metathesized segments in the words shown in (12) above.

$$
\text { (13) } \begin{array}{ll}
\text { sWV } & \text { SV } \\
-m-t^{\prime}- & -t^{\prime}-m- \\
-r-t^{\prime}- & -t^{\prime}-r- \\
-b-1- & -1-b- \\
-t^{\prime}-y^{-} & -\check{j}-t^{\prime}- \\
-d-g- & -g-d-
\end{array}
$$

Morpheme boundary assimilation

In morpheme boundary domains, only alveolar consonants undergo what may be called proper palatalization, where a consonant assimilates to the place and/or manner feature of a triggering vowel. This is illustrated by examples from the SV variety

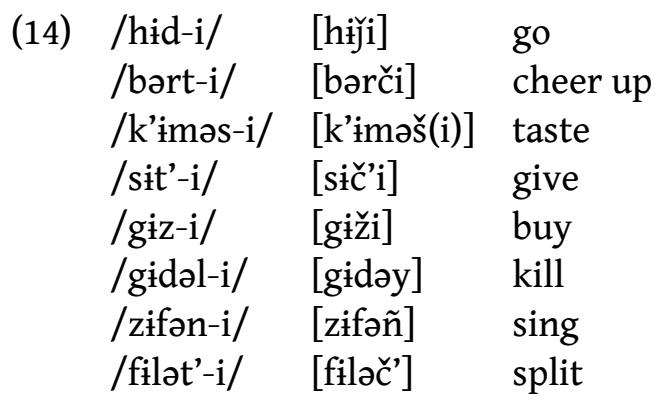

These are second person feminine imperative forms. The feminine morpheme is /-i/ and it triggers the palatalization, or weakening, of the stem-final alveo-dental consonants. The rule applies to all the coronal obstruents in the language in general, and is considered an areal feature (Ferguson 1976). What is peculiar to the variety of SW is that the rule extends to / $\check{c} /$ and $/ \check{\jmath} /$, which get weakened to $[\mathrm{y}]$ in word final position, as mentioned earlier. Observe the following examples: 
(15)

$\begin{array}{lll}\text { SWV } & \text { SV } & \\ {[\text { liyy }]} & {[1 \text { líj }]} & \text { child } \\ {[\text { məy }]} & {[\text { məč }]} & \text { when } \\ {[\text { dəy }]} & {[\text { dəy̆j] }} & \text { outdoor }\end{array}$

One would expect the central vowels /i/ and /a/ in the phonetic forms of the SW variety to undergo fronting, as they are followed by the palatal glide [y], which has the feature [+HIGH]. The forms should have been *[liy], *[mey] and $*$ [dey]. One possible reason for this could be that the fronting rule applies to verbs and their derivatives, whereas the triggering segment is a phoneme and not a positional variant, which is what [y] is in (15). It is a weakened variant of a palatal affricate /č/ or / $\breve{g} /$. Support for this comes from the examples in (16) below.

SWV

a. /hoyd-/

b. /həyd-all-əč / [hed-]

[hed-all-əy] /həyd- /

/hoyd-alləс̌/
SV

[hed-]

[hed-all-ə̌̌]

go

she has gone

In (a), the central vowel /a/ is realized as [e] because of the glide /y/, which is subsequently deleted. In (b), /č/ is realized as [y] in [hed-all-əy] 'she has gone' but the vowel /a/ preceding [y] has not undergone fronting.

In the context of negation, the liquid /l/ of the negative marker /al-/, assimilates in manner to the second person marker /-t/ in negative imperative stems like the following:

$$
\begin{array}{ll}
\text { /al-t-gərf-m/ } & >\text { [attigərfim] don't whip } \\
\text { /al-t-səbr-m/ } & >\text { [attisəbrim] don't break } \\
\text { /al-t-bəlam/ } & >\text { [attibəlam] don't eat }
\end{array}
$$

This rule of homorganic assimilation in manner only applies to the SW variety. In the standard variety, /l/ deletes, and /al-t-garf-m/ surfaces as [atgarfim] 'don't whip'. The choice is between deletion and assimilation of /1/, and the SW variety opts for the latter.

\section{Vowel harmonies}

There are morpheme and word boundary processes of vowel harmony attested in the present corpus. These are described in the following sub-sections. 


\section{(i) Centering}

A stem internal high front vowel may turn into high central, in the context of a preceding central vowel across a boundary. The following are illustrative examples:

\begin{tabular}{|c|c|c|}
\hline & SWV & SV \\
\hline /tolo/ & [ $\left.\mathrm{t}^{\mathrm{w}} \mathrm{ol} ə\right]$ & {$\left[\mathrm{t}^{\mathrm{w}} \mathrm{ol}^{\mathrm{w}} \mathrm{o}\right]$} \\
\hline
\end{tabular}

In 18 (a), the epenthetic vowel [i] is inserted to break up the initial cluster of /2-zz-/, which is not permissible. The stem internal high front vowel /i/ in [?izzih] 'here' changes to high central [i], in harmony with the epenthetic high central vowel of the prepositional enclitic [?i-]. In (b), the final mid back vowel /o/ of the second syllable of /tolo/ 'quickly' changes to mid central [ə] in the second syllable in /tolə /, in disharmony with the mid back vowel /o/ of the first syllable. This is attested in data from Borəna and Tənta. In data from other areas such as Lasta, in North Wallo, the process changes the vowel of the initial syllable in disharmony with the vowel of the second syllable. This means that the form /tolo/ 'quickly' surfaces as [təl $\left.{ }^{\mathrm{w}} \mathrm{o}\right]$ in this area.

In the language in general, perfective verb stems show the mid central vowel /o/ immediately after the initial and immediately before the final root consonant as in, for example, /səbbər-/ 'broke'. This is found in regular tri-literal verbs. In irregular verbs such as [hed-] 'went', which is derived from the phonemic representation /həyd-/, the glide triggers fronting of the vowel /a/ to [e] and then deletes, resulting in the stem [hed-], to which the third person suffix vowel [- a] is attached. In the SW variety, the glide triggers the medial consonant $/ d /$ to become palatalized to $\left[d^{y}\right]$, and then it (the glide) deletes. This results in the stem /had ${ }^{y}-/$, to which the same third person morpheme vowel /$\partial /$ is attached. Then the palatalized $\left[d^{y}\right]$ causes the suffix vowel /- $\partial /$ to become fronted to [e]. This process results in the form [həd $\mathrm{d}^{\mathrm{y}} \mathrm{e}$ ] 'he went'. The difference between the two varieties is in the direction in which the rule operates. In the standard variety, fronting applies to the vowel preceding the glide, whereas in the SW variety, raising applies to the consonant /d/ following it (the glide). In both cases, the glide deletes leaving its mark on the preceding or following segment. The cyclic application of the palatalization of $/ d /$ to $\left[d^{y}\right]$, and the fronting of the suffix vowel /-ə/ to [e], makes the process more complex in the SW variety.

[9] This is a reduced form of / $\mathrm{i}$-z-yih/ lit. 'from of this...' where /y/ assimilates to the preceding [z], a historical process also attested in other deictics. 
A similar process is observed in the following imperative/imperfective forms of the two varieties derived from the respective stems.

$\begin{array}{llll}\text { Perfective } & \text { Imperative/Imperfective } & \\ & \text { SWV } & \text { SV } & \\ \text { /həssəb/ } & \text { [issəb] } & \text { [assib] } & \text { think } \\ \text { /həggəz/ } & \text { [iggəz] } & \text { [aggiz] } & \text { help'/ 'assist } \\ \text { /həggad/ } & \text { [iggad] } & \text { [aggid] } & \text { stop from movement }\end{array}$

The perfective stems begin with the laryngeal, $/ \mathrm{h} /{ }^{10}$ in both varieties. In the imperative/imperative stem of the SW variety, /h/ deletes simply from the initial position and the epenthetic vowel [i] is inserted. In the SV, it deletes after the mid central vowel /a/ immediately following it has changed to low central [a], hence the contrast between [issab] [assib] 'think', for example. In the SV, the forms appear as [assib], [aggid] and [aggiz] with the epenthetic vowel [i] inserted in the penult position of the root, which results in the form [assib] ${ }^{11}$.

\section{(ii) Rounding}

There is a general rule that reduces a syllabic / $\mathrm{u} /$ to a non-syllabic [w], and a syllabic /i/ to a non-syllabic [y]. An instance of the former process is attested in the copula /nə-u/ 'it is', where the morpheme vowel /-u/ is weakened to the non-syllabic glide [w], leading to the form [now] 'it is'. Contrary to this, there is a rule that turns the palatal glide $/ y /$ to the labio-velar glide $[w]$, in the context of a high back morphemic vowel /-u/. Compare the following examples:

[10] The evidence for the presence of $/ \mathrm{h} /$ in such root initial position comes from the corresponding noun /hassab/ 'thought' and /hisab/ 'bill', in which /h/ appears. In the same way, /y/ and /w/ delete leaving their features on the sound adjacent to them.

[11] [assib] follows the pattern of verbs known as type ' $\mathrm{B}$ '. These are verbs that geminate their medial root consonant in both the perfective and imperfectve aspects, and insert the epenthetic vowel in the position preceding the last root consonant (Cowley, 1969). [issab] also follows the same pattern of type B verbs in geminating the medial root consonant, but it differs in inserting the epenthetic vowel in the position immediately after the deleted initial laryngeal consonant $/ \mathrm{h} /$. In this respect, the verb behaves partly like type A verbs, which shows the aspectual vowel, /ə/ in this position. But such verbs do not geminate the medial root consonant in the imperative/imperfective, unlike [issab], which does geminate its medial root consonant, perhaps in compensation for the lost initial laryngeal consonant. 
(20)

\begin{tabular}{|c|c|c|c|}
\hline $\begin{array}{l}\text { /t’’hay-u/ } \\
\text { /səmay-u/ } \\
\text { /lay-u/ }\end{array}$ & $\begin{array}{l}\text { SWV } \\
\text { [t'əhawu] } \\
\text { [səmawu] } \\
\text { [lawu] }\end{array}$ & $\begin{array}{l}\text { 'sun-DEF' } \\
\text { 'sky-DEF } \\
\text { 'upper-DEF' }\end{array}$ & 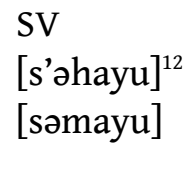 \\
\hline
\end{tabular}

As can be observed, the backing/rounding rule applies in the SW variety, the difference between the two varieties is one of applying or not applying the rule.

(iii) Lowering and rounding

The high back vowel / $\mathrm{u} /$ turns into a mid back [o] in the context of a following mid back suffix vowel /-o/. Consider the following examples derived from the corresponding stems:

\begin{tabular}{|c|c|c|c|}
\hline & $\begin{array}{l}\text { SWV } \\
{\left[\mathrm{m}^{\mathrm{w}} u \mathrm{t}^{\mathrm{w}}-\mathrm{o}\right]}\end{array}$ & $\begin{array}{l}\text { SV } \\
{\left[\mathrm{m}^{\mathrm{w}} \mathrm{ot}^{\mathrm{w}}-\mathrm{o}\right]}\end{array}$ & he, having died \\
\hline /dul/ & {$\left[\mathrm{d}^{\mathrm{w}} \mathrm{ul}^{\mathrm{w}}-\mathrm{o}\right]$} & {$\left[\mathrm{d}^{\mathrm{w}} \mathrm{ol}^{\mathrm{w}}-\mathrm{o}\right]$} & he, having entered something \\
\hline /hun/ & {$\left[\mathrm{h}^{\mathrm{w}} \mathrm{un}^{\mathrm{w}}-\mathrm{o}\right]$} & {$\left[\mathrm{h}^{\mathrm{w}} \mathrm{on}^{\mathrm{w}}-\mathrm{o}\right]$} & he, having become \\
\hline
\end{tabular}

Word boundary assimilation

In the preceding sub-sections, morpheme boundary phonological processes have been examined. In this sub-section, harmonic processes that take place across word boundaries will be examined.

\section{(i) Centering}

In the SW variety, the high back vowel / $\mathrm{u} /$ in the second syllable of the adjective / $t$ '-ru/ 'fine' turns into the mid central [ə] in harmony with the mid central /ə/ of the noun /work' / 'gold', and subsequently the epenthetic rule applies to the position following the initial consonant in/ $t$ '-ru/ 'fine'. Compare the following forms:

$$
\begin{array}{lll} 
& \text { SWV } & \text { SV } \\
\text { t'-ru wark'/ } & \text { ['tira wark'] } & {\left[\mathrm{t}^{\prime} \mathrm{ir}^{\mathrm{w}} \mathrm{u}\right. \text { wark'] fine gold }}
\end{array}
$$

In the SV, only the rounding rule applies to $/ \mathrm{r} /$ which surfaces as $\left[\mathrm{r}^{\mathrm{w}}\right]$.

[12] A reviewer commented that the [w] in such forms could be epenthesis in the forms of the SW variety. The suggestion implies the deletion of the stem-final glide /y/ in t'ahay 'sun' and samay 'sky' and the production of bound stems to which the morpheme vowel /-u/ is suffixed. This results in the forms /t’aha-u/ and /səma-u/, into which is inserted /w/to break up the impermissible sequencing of the two vowels. I see no motivation for the deletion of the stem-final glide $/ y /$ in the first place and the production of bound stems. Secondly, the definite suffix /-u/ is only attached to words such as nouns and adjectives, and not to bound stems. 
(ii) Fronting

In the following locative interrogative structure, the second syllable of the locative preposition /wadə/ 'to' truncates, and the remaining part /wo-/ restructures itself with the interrogative pronoun /yat/ 'where'. This leads to an indivisible unit, to which a number of rules apply. Observe the following:

/wadə yat nə-u /

to where be-it

to where is it that

First, the syllable /-də/ of the preposition /wadə / is truncated and the remaining part, that is /wo-/, is restructured with the locative pronoun /yat/ across word boundary, resulting in the form [wəyət/ 'where'. Then, the final consonant $/ \mathrm{t}$ / of this new form, /woyat/, assimilates totally to the initial nasal /n/ of the copular predicate /no-u/ 'it is', again across the boundary. This leads to the surface form /wəyənnə-u/ 'where is it? Then a fronting rule applies to the second /a/ which turns into [i] because of the glide /y/ preceding it. Finally, a weakening rule reduces /- $\mathrm{u} / \mathrm{in} / \mathrm{n} ə-\mathrm{u} /$ to $[\mathrm{w}]$, resulting in an indivisible phonetic form [wəyinnəw] 'where is it?

This is in the SW variety. In the SV, the glide /y/ of the pronoun /yat/ 'where' deletes, after it has triggered the mid central vowel /ə/ following it to change to mid front, [e ]. Then, the rhyme, /-et/, of the syllable, [yet] 'where' is restructured with the preposition /wadə/ 'to', resulting in the form /wadə-et/ 'where'. The central vowel /a/ of /wadə/ 'to' is deleted because of the high front tense vowel /e/ of the rhyme /-et/ following it. This results in the form /wadet/. Then / $\mathrm{t} /$ of this form assimilates to the nasal / $\mathrm{n} /$ of the predicate, /nə-u/ 'it is'. This yields the surface form, [wədennəw] 'where is it'. The difference between the two varieties is in the degree of truncation. In the SW variety, an entire syllable is truncated, whereas in the SV, only the onset glide /y/ of /yat / 'where' is deleted. In both varieties, restructuring is followed by assimilations leading to the forms [wəyinnəw] in the SW variety, and [wadennəw] in the SV, both meaning 'where to'?

\section{(iii) Deletion and rounding}

There are deletion rules applying to the final consonant of the interrogative pronoun /mən/ 'what', followed by rules of vocalic harmony and disharmony operating on the vowel of the remaining part of the same pronoun, which is much the same as what happens to the pronoun /yat/ 'where' considered above. 
(24)
a. /min hun -o/
SWV
SV
what became-3MSG
what became of him?
b. /min hon $-\mathrm{k} /$
$\left[\mathrm{m}^{\mathrm{w}} \mathrm{uh}\right.$ $\left.\mathrm{yk}\right] \quad\left[\mathrm{minh}^{\mathrm{w}} \mathrm{y} \mathrm{yk}\right]$
what became-2MSG
what became of you?

In the interrogative phrase in 24 (a), the final segment $/ \mathrm{n} /$ of the pronoun $/ \mathrm{min} /$ 'what' deletes in the context of a following inchoative predicate, and the high central vowel $/ \mathfrak{i} /$ preceding the deleted nasal of the same pronoun turns into a high back, in harmony with the high back vowel $/ \mathrm{u} /$ of the first syllable of the inchoative predicate /hun-o/ 'having become'. In 24 (b), the same deletion rule applies to the final nasal of the interrogative pronoun / $\mathrm{min} /$ 'what'; the high central vowel, /i/ preceding it turns into high back [u], again in harmony with the mid back vowel /o/ of the inchoative predicate. Then, the mid back vowel /o/ of the inchoative predicate turns into the mid central vowel $/ \partial /$, in disharmony with the high back vowel $[\mathrm{u}]$ of the interrogative pronoun.

Following the deletion of $/ \mathrm{n} /$ of $/ \mathrm{min} /$, one harmonic, and one disharmonic rule applies in cycles. The disharmonic rule operates on the output of the deletion rule which elides the final nasal of the pronoun, and on the forms that result from the restructuring of the remaining pronoun with the inchoative predicate.

\section{[5] SUMMARY}

The objective of this study was to undertake a further description of the variety of Amharic spoken in South Wallo. In previous literature (Amsalu and Habtemariam 1973) it was claimed that Amharic had shown variations across the provinces of Gondər, Gojjam, Wəllo and Shewa. This was based on an assumption that the Amharic used in the capital city, Addis Ababa, was de fact standard as it was the language of power, propagated by the media as an expression of formal communication in institutions such as schools, courts, churches, etc. The few attempts made to describe the variations, showed that the Wallo variety had lexical and phonological peculiarities such as palatalized alveo-dentals like $\left[\mathrm{d}^{\mathrm{y}}, \mathrm{t}^{\mathrm{y}}, \mathrm{t}^{\mathrm{y} y}\right.$ etc], a tendency for central vowels instead of front vowels and weakening of alveo-palatals. It was also reported that the variety was characterized by a large number of Arabic and Oromo words caused by longstanding socio-cultural contact that led to lexical diffusion.

The studies were based on data from three urban and semi-urban sites: Haik', Sulula and Ambassal. The present attempt, in contrast, is based on rec- 
orded corpus from eight of the 20 districts of the present South Wallo Zone. The focus of the description is on the phonetic segments and the phonological process attested in the corpus.

From the recorded corpus of narratives, 49 consonants have been identified, of which 26 consonants and seven vowels have been recognized as phonemes, making a total of 33 against the 37 recognized for the standard variety. The difference is in the labio-velars $/ \mathrm{k}^{\mathrm{w}}, \mathrm{g}^{\mathrm{w}}, \mathrm{k}^{\mathrm{w}}$, and $\mathrm{h}^{\mathrm{w}} /$ which are missing in the Wallo variety as phonemes, but occur as results of a phonological process of rounding (labialization). It has also been attested in the present corpus that the velar stops have spirantized counterparts, occurring in intervocalic positions. Furthermore, the phonetic inventory of vowels includes a low front vowel [æ] which is considered a result of coalescence of $/ \mathrm{i} /$ and $/ \mathrm{a} /$. In the standard variety, /i/ is weakened to [y], instead of coalescing with /a/. Thus, /zabia/ surfaces as [zaß $\left.\aleph^{y} a\right]$ and not as [zaßæ], 'handle'.

The seven vowels and the 26 consonant phonemes fall into structures of syllables with a non- branching optional onset, and a branching optional coda of two segments on which the phonological rules operate. Such rules include primary palatalization of anterior and coronal obstruents, weakening of alveopalatal affricates, and spirantization of velars stops; sporadic (lexeme-specific) alternations between the simple alveo-dental stops $/ \mathrm{t} /$ and $/ \mathrm{d} /$ and the sonorants /n/ and /r/; morpheme boundary assimilations, and word boundary truncation of parts of a syllable, followed by restructuring of the remaining part with the rest of a constituent. The study has also shown variations in the directionality, and cyclicity of rules of vocalic harmony attested in the SW variety.

\section{AC KNOWLEDGMENTS}

This research is part of a project on Linguistic Capacity Building: Tools for Inclusive Development in Ethiopia, financed by the Norwegian Program for Capacity Development in Higher Education and Research for Development (NORHED). I am grateful to Ronny Meyer for helpful comments and queries, and to my audience at the workshop in Rondane, where the first draft was presented. I also appreciate helpful comments received from reviewers. The usual disclaimer holds.

\section{REFERENCES}

Amsalu Aklilu and Habtemariam Marcos. 1973. Regional Variation in Amharic: the Dialect of Wallo. Journal of Ethiopian Studies, Vol. 11:2 (124-129).

Appleyard, David. 1977. A Comparative Approach to the Amharic Lexicon. Afroasiatic Linguistics, 5:2 (1-67). 
Appleyard, David. 2003. Amharic. In Uhlig, Siegbert (ed). Encyclopaedia Aethiopica. Vol. 1, (233-234). Wiesbaden: Harrassowitz Verlag.

Baye Yimam. 2000 (EC). Amharic Grammar (in Amharic, 2nd ed.). Addi Ababa: Eleni Publishers.

Bender, et al. (eds.). 1976. Language in Ethiopia. London: Oxford University Press.

Bender, L. 1976. The Amharic Language. In Bender, et al. (eds.). Language in Ethiopia. (77-98). London: Oxford University Press.

Bender, Marvin L. 1983. The Origin of Amharic. Journal of the Institute of Language Studies. Vol. 1:1, (41-52).

Chomsky, Noam and Halle, Morris. 1968. Sound Pattern of English. New York: Harper.

Cowley, Roger. 1969. A and B verbal stem - type in Amharic. Journal of Ethiopian Studies. Vol. 7:1, (1-14).

Ferguson, Charles. 1976. The Ethiopian Language Area. In Bender et al. (eds.). Language in Ethiopia. (4-76). London: Oxford University Press.

Gebre Bizuneh. 1999. Linguistic Survey of the Amhara Regional State. Culture and Tourism Bureau, Bahr Dar. Unpublished.

Getahun Amare. 1983. The Dialect of Wallo with a Special Reference to the Ambassel Awaja. Unpublished Senior Essay in Linguistics, Department of Linguistics, Addis Ababa University.

Gragg, G. 1976. Oromo of Wellega. In Lionel Bender (ed). The Non-Semitic Languages of Ethiopia. (166-196). East Lansing: African Studies Center, Michigan State University.

Hailu Fulass and Fisseha Sisay. 1973. Regional Variation in Amharic: The Dialect of Manz. Journal of Ethiopian Studies. Vol. 11:2, (120-124).

Hailu Fullas, Getachew Haile, and Roger Cowley. 1976. Dialect Variation in Amharic. In Bender et al. (eds.). Language in Ethiopia. (90-99). London: Oxford University Press.

Hussein, Ahmed. 2001. Islam in Nineteenth Century Wallo, Ethiopia: Revival, Reform, and Reaction. Leiden: Brill.

Kebede Hordofa. 2009. Towards the Genetic Classification of the Afaan Oromoo Varie- 
ties, PhD Dissertation, University of Oslo.

Leslau, Wolf. 1945. The Influence of Cushitic on the Semitic Languages of Ethiopia. A Problem of Substratum. Word. Vol. v:1, (59-82).

Leslau, Wolf. 1964. Towards a History of the Amharic Vocabulary. Journal of Ethiopian Studies. Vol. II:2 (12-20).

Leslau, Wolf. 1995. A Reference Grammar of Amharic. Wiesbaden: Harrassowitz Verlag.

Pankhurst, Alula. 1994. Indigenizing Islam in Wəllo: Ajemi, Amharic verse written in Arabic script. In Bahru Zewde, R. Pankhurst, Taddese Beyene (eds.). Proceedings of the Eleventy Internaltional Conference of Ethiopian Studies, Vol. ii, (257-273). Institute of Ethiopian Studies, Addis Ababa University.

Rukia Hassen. 2013. An Ethnography of Communication of the Amharic Speaking Muslim Community of South Wallo, PhD Thesis Submitted to the Department of Foreign Languages and Literature, Addis Ababa University.

Taddese Beyene. 1972. Aspects of the verb in Amharic. PhD thesis, Georgetown University.

Zelealem Leyew. 2007. Amharic Varieties Revisited. In Rainer Voigt, (ed). Semitohamitica Berolinensia 5, (449-480).

CONTAC T

Baye Yimam

Addis Ababa University

bayemekonnen@gmail.com

baye.yimam@aau.edu.et 